\title{
Administration Safety of Blood Products - Lessons Learned from a National Registry for Transfusion and Hemotherapy Practice
}

\author{
Thomas Frietsch ${ }^{a}$ Daffyd Thomas ${ }^{b}$ Michael Schöler ${ }^{c}$ Birgit Fleiter ${ }^{d}$ Martin Schipplick ${ }^{e}$ \\ Michael Spannagl ${ }^{f}$ Ralf Knels ${ }^{g}$ Xuan Nguyen ${ }^{\text {h }}$ \\ a Department of Anesthesiology and Critical Care Medicine, Diakonissenkrankenhaus Mannheim, Teaching Hospital of the University \\ Medicine Mannheim, University of Heidelberg, Mannheim, Germany; \\ ${ }^{b}$ Department of Anaesthesia and Critical Care, Morriston Hospital, Swansea, Wales, UK; \\ ${ }^{c}$ Department of Anesthesiology and Surgical Intensive Care Medicine, University Medical Center Mannheim, Mannheim, Germany; \\ dDRK Blutspendedienst West, Nordrhein, Germany; \\ e Department of Anesthesiology and Critical Care Medicine, Krankenhaus Leonberg, Leonberg, Germany; \\ ${ }^{f}$ Department of Hemostasis and Transfusion Medicine, Ludwig-Maximilians-University of Munich, Munich, Germany; \\ g Medical Care Center Dresden, Labor Moebius, Dresden, Germany; \\ h Duc's Laboratories, Amita Monestry, Mannheim, Germany
}

\section{Keywords}

Error - Critical incidents - Hemotherapy .

Transfusion safety · Error reporting - Confusion .

Right tube - Right patient - Administration safety

\section{Summary}

Background: Compared to blood component safety, the administration of blood may not be as safe as intended. The German Interdisciplinary Task Force for Clinical Hemotherapy (IAKH) specialized registry for administration errors of blood products was chosen for a detailed analysis of reports. Methods: Voluntarily submitted critical incident reports ( $n=138$ ) from 2009 to 2013 were analyzed. Results: Incidents occurred in the operation room $(34.1 \%)$, in the ICU $(25.2 \%)$, and in the peripheral ward (18.5\%). Procedural steps with errors were administration to the patient $(27.2 \%)$, indication and blood order (17.1\%), patient identification (17.1\%), and blood sample withdrawal and tube labeling (18.0\%). Bedside testing (BST) of blood groups avoided errors in only $2.6 \%$. Associated factors were routine work conditions (66\%), communication error (36\%), emergency case (26\%), night or weekend team (39\%), untrained personnel (19\%). Recommendations addressed process and quality ( $n=479$ ) as well as structure quality $(n=314)$. In 189 instances, an IT solution would have helped to avoid the error. Conclusions: The administration process is prone to errors at the patient assessment for the need to transfuse and the application of blood products to patients. BST is only detecting a minority of handling errors. According to the expert recommendations for practice improvement, the potential to improve transfusion safety by a technical solution is considerable.

(c) 2017 S. Karger GmbH, Freiburg

\section{Introduction}

The German transfusion law [1] and the cross-sectional guidelines for the use of blood and blood products of the German Medical Association [2] apply evidence-based recommendations for the use of each blood product. Their implementation and practical compliance are promoted by an obligatory structure of dedicated quality managers of hemotherapy, dedicated responsible physicians in every institution, and dedicated assigned physicians in each department for the correct use of blood and blood products. A transfusion committee meeting regularly discusses current problems to improve efficacy and safety of hemotherapy. Furthermore, the use of blood and blood product production are regulated by German pharmaceutical law since they are categorized pharmaceu-

\section{KARGER}

() 2017 S. Karger GmbH, Freiburg 
tical products. Documentation of internal or external audits has to be reported to regulatory bodies. Hemovigilance reports are published by the Paul-Ehrlich-Institut (PEI), reporting statistics of major transfusion reactions as well as blood product donation, use, and discard [3]. Bedside confirmation of recipient's identity and $\mathrm{ABO}$ blood group is undertaken prior to red cell transfusion. Bedside testing (BST) is obligatory in Germany for the administrating physician. Such confirmation testing for blood groups $\mathrm{ABO}$ and $\mathrm{ABO}+\mathrm{D}$ is also used in a few other European countries. It confirms patient identity at the bedside immediately before a blood transfusion is started. In addition, BST is intended to confirm the recipient's $\mathrm{ABO}$ blood group antigens (of lesser vital importance $\mathrm{D}$ ) previously determined and thus ensures that there is a match between the recipient's blood group and the blood product. Dependent on the producer of the little test cards, anti-serums for A and B (D) are either to be mixed with the drop of patient's blood (SERAFOL) or are in a liquid compartment where the blood must be injected into (MEDTRO). Agglutination of the red cells with the anti-serum becomes visible and should match the blood group of the blood product to be given. This identifies any incompatibility that may occur if the patient or the blood product had been confused.

Transfusion safety in Germany is believed to be sufficiently robust at state-of-the-art level. Underreporting of safety issues in Germany is not a major concern. Whereas fatal errors resulting in acute hemolytic transfusion reactions are documented in the PEI hemovigilance registry (ranging from 1 to 3 per million in recent years), an underreporting of incorrect allocation of products (risk of incorrectly transfused blood components 0.2 per million) must be assumed. In absence of hard data, incidences of non-fatal errors in the German system were estimated between 1:32,000 [4] and 1: 36,000 [5], whereas data from the USA reported higher figures in the range from $1: 12,000$ to $1: 19,000$ [6].

To challenge and improve the blood transfusion safety standard in Germany, a dedicated critical incident reporting system (CIRS) for Germany was set up on a voluntary basis in 2009 [7] as a joint venture of the German Interdisciplinary Task Force for Clinical Hemotherapy (IAKH) [8] and the German Interdisciplinary Society of Critical Care and Emergency Medicine (DIVI). Free of charge and accessible for the public, error reporting in the IAKH error registry $[9,10]$ is encouraged for every user of autologous and allogeneic blood in every health care institution in Germany. As opposed to the PEI registry, any kind of error or critical incident associated with the administration of blood and coagulation products voluntarily can be reported by physicians and other medical staff. Reports were analyzed and categorized by an interdisciplinary committee of transfusion medicine specialists, internists, surgeons, and anesthesiologists. Critical incidents referring to transfusion issues from the German Anesthesiology Societies (DGAI and BDA) CIRS-AINS medical [11] were also surveyed on behalf of the BDA by the IAKH committee and included in the IAKH error registry database.

This article addresses the character of reported errors and critical incidents within the administration process of blood products after a 5 -year period. Errors in blood product administration were analyzed for circumstances, relevance, risk of damage, and contributing factors. The publication of committee's recommendations may be of common interest for other than the reporting institutions - therefore, they are listed and grouped as proposed strategies of quality improvement.

\section{Material and Methods}

\section{Database and Reporting Form}

In 2009, the website went online, and the reporting was encouraged by information in the national medical press $[7,10]$. In parallel, the German BDA started an anesthesia-based critical incident reporting system. All incidents concerning a blood product were sent to the IKAH committee for analysis and entry in the IAKH database. The multidisciplinary IAKH committee is constituted of experts from various clinical departments. All aspects of an error report were addressed by the respective specialist either in the committee's session or by requiring re-submittal after analysis.

To avoid a double entry of the same incident, each report is anonymized by coding the individual case with the third letter as well as the number of letters of the first and surname of the patient. The first letter of the area code of the reporting institution had to be given. In each type of entry form, general information such as the American Society of Anesthesiologists risk class (ASA) stratification of the patient according to the perioperative system by the American Society of Anesthesiologists, the location where the incident happened, and which profession detected the error is to be entered. The free accessible web page of error reporting initially had 5 entry forms to report a critical incident categorized by the process steps: 1) blood product order for each incident that happens before, after, or while ordering a blood product from the blood bank or depot including the assessment of the need of transfusion; 2) blood group sample withdrawal and tube labeling for each incident that happens before, after, or while blood withdrawal for type and screen, labeling and sending to the immunology laboratory; 3) laboratory handling of blood probes, type and screen, or release of ordered blood for all incidents in the laboratory, blood bank and depot from arrival of a blood probe until release of a blood or coagulation product to the user or transport system; 4) transport and handling of blood products for incidents happening while and associated to transport and storage of blood products, 5) blood product administration for all incidents happening immediately before, while, or after administration of the blood product to the recipient, identification of the patient, performance of BST, starting of the transfusion and documentation, 6) for other incidents such as coagulation management, autologous processing, or donation. The last form was introduced later and went active in January 2013. The shorter collection period of this type of error is considered in the analysis. All minor process steps covered by the 6 forms are given in table 1. Definition of errors and their categories are listed in table 2.

\section{Analyses, Definitions, and Categories}

In addition, during the work process with the registry, a frequent error located before the process chain even starts was recognized by the committee the indication to transfuse frequently was not in congruence with the existing guidelines. Without creating a special entry form for that, the correctness of the transfusion indication was tested. The same applied for the patient identification and confusion error. This critical step occurs several times in the administration process - prior to type and screen, blood withdrawal, or blood product administration. The information about a correct or incorrect performance of the BST is required by the IAKH report form. The classification of an error into one or more process steps was done by the committee even if the incident was classified differently by the reporter in accordance to the given categorization of errors (table 2).

The incoming reports were edited and discussed among committee members in a secured phone conference weekly. Reports and categories of errors were entered in a database. Results are given in absolute counts or errors in the reported cases as well as in percentage of the 5 year's sum of all errors reported. 
Table 1. Process steps covered by the reporting form

\begin{tabular}{lll}
\hline Form & Category description & Step \\
\hline 1) Blood product order & $\begin{array}{l}\text { Each incident that happens before, after, } \\
\text { while ordering a blood product from the } \\
\text { blood bank or depot including the } \\
\text { assessment of the need of transfusion }\end{array}$ & $\begin{array}{l}\text { a) Identification of the patient by entry in the hospital's PDMS during the } \\
\text { admittance in administration, ICU or emergency unit Assessment of the need } \\
\text { of transfusion in a clinical situation of an individual by clinical situations, } \\
\text { symptoms, laboratory and history }\end{array}$ \\
& $\begin{array}{l}\text { b) Order of the right number of units or products by delegation, by filling an } \\
\text { electronic or analog order form for this patient }\end{array}$ \\
& $\begin{array}{l}\text { c) Organization of process initiation by defining time, dose, clinical situation } \\
\text { and urgency, responsibility }\end{array}$
\end{tabular}

2) Blood group sample withdrawal and tube labeling

3) Laboratory handling of blood probes and products
Each incident that happens before, after, while blood withdrawal for type and screen, labeling and sending to the immunology laboratory

Each incident that happens before during and after blood probe arrival, screen and type, release of ordered blood for all incidents in the laboratory, blood bank and depot from arrival to release of a compatible product a) Preparation of blood containers, printing and labeling for the right individual b) Identification of the right patient for the blood withdrawal Blood withdrawal off the right patient in correct labeled containers at the right time

Errors of blood probe reception

a) Acceptance of blood probes without correct labeling, in wrong tubes, insufficient volume, outdated since leaving the patient

b) Mismatch at reception of blood probes for type and screen, confusion of attached documents

Errors of blood group test either in an analyzer, gel cards, elution or other methods including

c) Wrong results, no results despite antibody detectable, wrong diagnostic tool such as choose of wrong antibody panel,

d) Delays in working on emergency cases associated with analysis, result reading, further diagnostic, and result output

Errors associated to release of blood products while

e) Retrieval of correct tested blood unit from storage

f) Product checking out

g) Releasing documentation and signature to the authorized person

4) Transport and handling of blood products
Each incident that happens on and with transport of probe from patient to laboratory, from probe transport to analyzer, blood product transport and storage within the blood depot, blood product transport from blood depot to the sub-depot or to the patient a) Incorrect transport conditions i.e. temperature, box, contamination, not approved storage condition, etc.

b) Avoidable delays of urgent deliveries

c) Mix-up and confusion of several products for various recipients

d) Damage to or loss of products

e) Inadequate handling of probe during transport and waiting period for application, i.e. no agitation and extended storage of platelets

\section{5) Blood product administration \\ Each incident that happens prior to product application to the recipient}

a) Bedside test not done, wrong done, wrong interpreted, done from the wrong patient

b) Mismatch of blood group documents of patients, blood group information on blood product and BST

c) Inadequate preparation of products and transfusion sets, i.e. incomplete thawing, incomplete visual control of red cells for hemolysis

d) Inadequate application condition, illegal delegation, inadequate venous access, wrong application mode or period, etc.

e) Flawless documentation of application process

f) No or insufficient monitoring during transfusion

g) Any other administration error

\section{6) Patient identification Each incident that happens while} receiving, documenting, matching the identity of patients, blood products or probes a) Wrong patient ID at hospital admission due to mix-up, wrong ID given, wrong or no wrist band, unconsciousness and later misallocation of emergency number to ID

b) Wrong identification procedure prior to withdrawal of blood probe or application of blood product

7) Others such as coagulation management, autologous processing or donation
Each incident that occurs in hemotherapy but does not fit the above classification within the process chain a) Problems with or during production of autologous products by cell salvage and preoperative donation

b) Problems with coagulation management, i.e. incorrect diagnostics, choosing the incorrect antidote or insufficient dosage, overdose, etc.

c) Any other error not covered by any previous entry form

PDMS = Patient data management system; ICU = intensive care unit; ID = identity. 
Table 2. Definition of error/incident categories (modified from SHOT categories)

\begin{tabular}{|c|c|c|}
\hline Error category & Subcategory & Error/incident definition \\
\hline \multirow{5}{*}{$\begin{array}{l}\text { Avoidable, delayed or } \\
\text { undertransfusion } \\
\text { Near misses are not included }\end{array}$} & Avoidable & $\begin{array}{l}\text { Blood product unnecessary transfused according to guidelines with respect to clinical } \\
\text { situation / laboratory values. Discarded blood products due to outdated or incorrect }\end{array}$ \\
\hline & & $\begin{array}{l}\text { storage conditions, late return to the supply chain (reports of not indicated transfusions } \\
\text { are not included- see Administration error, Indication below) }\end{array}$ \\
\hline & Delayed & Time delay by an error that happened earlier in the administration process \\
\hline & Over transfusion/TACO & Transfusion associated circulatory overload, overdosing of blood product \\
\hline & $\begin{array}{l}\text { Coagulation management } \\
\text { and dosing error }\end{array}$ & $\begin{array}{l}\text { Wrong dosing or error in coagulation management associated to the use of plasma and } \\
\text { coagulation factors incl. concentrates, prothrombin complex, cryoprecipitate etc. }\end{array}$ \\
\hline \multirow[t]{5}{*}{$\begin{array}{l}\text { Incorrect blood component } \\
\text { transfused }\end{array}$} & $\begin{array}{l}\text { General requirements not } \\
\text { met }\end{array}$ & $\begin{array}{l}\text { Wrong kind of blood product transfused (packed red cells, platelets, plasma, coagulation } \\
\text { factors, outdated products, allogeneic instead of autologous etc.) }\end{array}$ \\
\hline & Unmatched & $\begin{array}{l}\text { Unmatched or universal } 0 \text { negative red cells, not blood group matched platelets or } A B \\
\text { fresh frozen plasma in elective cases, application of blood products unscreened for } \\
\text { antibodies or compatibility }\end{array}$ \\
\hline & Incompatible & $\begin{array}{l}\text { Real administration (not near misses) of incompatible blood with respect of major } \\
\text { blood group or allo-antibodies }\end{array}$ \\
\hline & Compatible & Compatible blood but wrong recipient \\
\hline & $\begin{array}{l}\text { Specific requirements not } \\
\text { met }\end{array}$ & $\begin{array}{l}\text { Although necessary no irradiation, leukodepletion, washed, frozen, Jehovah witnesses } \\
\text { transfused without consent etc. }\end{array}$ \\
\hline $\begin{array}{l}\text { Errors related to cell salvage } \\
\text { and preoperative donation }\end{array}$ & $\begin{array}{l}\text { Production of autologous } \\
\text { products }\end{array}$ & $\begin{array}{l}\text { Use and production of autologous products including preoperative donation and } \\
\text { operation of cell saver device } \\
\text { Cell saver defect, technical malfunction } \\
\text { Mismatch of products following disconnection or confusion of autologous products }\end{array}$ \\
\hline \multirow[t]{2}{*}{ Patient identification (ID) } & $\begin{array}{l}\text { Type and screen probe } \\
\text { bedside test or laboratory }\end{array}$ & $\begin{array}{l}\text { ID of patient not or wrong done, test withdrawn from wrong patient } \\
\text { Laboratory test (hemoglobin levels, coagulation values or bedside test from wrong } \\
\text { patient }\end{array}$ \\
\hline & Blood / coagulation product & Administration of blood /coagulation product to the wrong patient \\
\hline \multirow{2}{*}{ Labeling } & $\begin{array}{l}\text { Labeling of chart or other } \\
\text { documents }\end{array}$ & Label not applied on chart or documents, incorrect label from other subject, wrong \\
\hline & $\begin{array}{l}\text { Labeling of blood products / } \\
\text { coagulation products / drugs }\end{array}$ & Confused label on covers from other subjects, wrong content names or dosages \\
\hline \multirow[t]{2}{*}{ Laboratory } & Laboratory error & $\begin{array}{l}\text { Wrong test results due to pre-analytic errors, diluted blood, test result issued for wrong } \\
\text { subject, blood sample for antibody cross match expired, wrong blood sample sent, etc. }\end{array}$ \\
\hline & Testing error & analyzer defect or calibration missed, wrong POCT operation \\
\hline \multirow[t]{3}{*}{ Storage } & Storage error & $\begin{array}{l}\text { Storage error of blood products (including ' } 30 \text {-min rule'), extended storage in sub-depot } \\
\text { location, extended non-agitated storage of platelets, unapproved storage in a food or } \\
\text { drug refrigerator }\end{array}$ \\
\hline & $\begin{array}{l}\text { Temperature deviation / } \\
\text { cold chain error }\end{array}$ & $\begin{array}{l}\text { Storage temperature deviations due to use of inappropriate storage i.e. warming or } \\
\text { cooling devices }\end{array}$ \\
\hline & Component expiry & Use of outdated products \\
\hline Product release /issue & $\begin{array}{l}\text { Product / component issue / } \\
\text { release }\end{array}$ & $\begin{array}{l}\text { Mismatch or confusion at off-charge of product off the depot or blood bank, wrong or } \\
\text { inappropriate component issued, wrong unit logged out, adjusting error, incomplete } \\
\text { check out, documentation error }\end{array}$ \\
\hline Transport & Transport error & Inadequate transport conditions, duration, products for multiple recipients in one box \\
\hline $\begin{array}{l}\text { Administration error } \\
\text { Indication }\end{array}$ & Indication & $\begin{array}{l}\text { Erroneous indication for transfusion due to lab or pre-analytic error, missing guideline } \\
\text { coverage due to misinterpretation of lab values, clinical context, circulatory symptoms, } \\
\text { volume status or ignorance }\end{array}$ \\
\hline \multirow[t]{4}{*}{ Blood management } & $\begin{array}{l}\text { Uncorrected preoperative } \\
\text { anemia }\end{array}$ & Uncorrected preoperative anemia in elective surgery \\
\hline & $\begin{array}{l}\text { Transfusion trigger } \\
\text { unrecognized }\end{array}$ & Restrictive transfusion strategy as suggested by guidelines \\
\hline & Urgency of blood use & Not indicated emergency administration of not cross-matched, universal blood \\
\hline & $\begin{array}{l}\text { Volume status related to } \\
\text { transfusion }\end{array}$ & $\begin{array}{l}\text { Missing volume replacement for hyper-/hypovolemia, unsecure volume monitoring, } \\
\text { blood products used for volume resuscitation }\end{array}$ \\
\hline
\end{tabular}


Table 2. Continued

\begin{tabular}{|c|c|c|}
\hline Error category & Subcategory & Error/incident definition \\
\hline Consent & Informed consent not done & $\begin{array}{l}\text { Information about risks and complication of blood transfusion for conscious subjects } \\
\text { and elective transfusion wrong or not done or not documented }\end{array}$ \\
\hline Blood order & Blood order error & $\begin{array}{l}\text { Missing or incorrect blood order, blood order for wrong patient, missing data on order } \\
\text { form, etc. }\end{array}$ \\
\hline Bedside test & Bedside test & Not or wrong done, wrong interpretation \\
\hline \multirow[t]{6}{*}{$\begin{array}{l}\text { Preparation for blood } \\
\text { product administration }\end{array}$} & Type and screen, crossmatch & $\begin{array}{l}\text { Missed/undone or wrong done type and screen, blood product reservation for elective } \\
\text { transfusion or scheduled surgery, no antibody differentiation ordered }\end{array}$ \\
\hline & Pretransfusion procedure & $\begin{array}{l}\text { immediately prior to blood product administration :lab value check, matching control } \\
\text { of blood product ID blood group and patient blood group, antibody screen test, outdate } \\
\text { of blood product, visual blood product control, transfusion system, venous access etc.) }\end{array}$ \\
\hline & Timing & $\begin{array}{l}\text { Inadequate timing of administration including premature timing of anesthesia before } \\
\text { blood availability (induction of anesthesia without blood availability check) }\end{array}$ \\
\hline & Delegation of transfusion & Start of transfusion cannot be delegated by German transfusion law \\
\hline & Multiple transfusion & $\begin{array}{l}\text { More than one transfusion process, more than one patient synchronously or massive } \\
\text { transfusion as contributing factor or error }\end{array}$ \\
\hline & Double unit administration & Ordering and transfusion of two units without review \\
\hline Monitoring & $\begin{array}{l}\text { Monitoring during adminis- } \\
\text { tration }\end{array}$ & Vitals and clinical symptoms monitoring for transfusion reaction not done \\
\hline \multirow[t]{2}{*}{ Documentation } & $\begin{array}{l}\text { Documentation of } \\
\text { administration }\end{array}$ & Undone or wrong done documentation of administration of blood products \\
\hline & $\begin{array}{l}\text { Inadequate timing of } \\
\text { administration }\end{array}$ & For example at night time without urgency \\
\hline \multirow[t]{7}{*}{ Errors related to IT } & Wrong record selected & $\begin{array}{l}\text { IT user based error: selection of wrong record and/or mismatch of order, test result or } \\
\text { written entry to the wrong file/record. Attribution of diagnoses or diagnostic findings } \\
\text { to the wrong chart/record by computer, analyzers or the operator manually, due to i.e. } \\
\text { similar name, ID number or small font }\end{array}$ \\
\hline & $\begin{array}{l}\text { Failure to consult or identify } \\
\text { historical record }\end{array}$ & $\begin{array}{l}\text { IT based or user based error: failure to retrieve a historical record in the data base with } \\
\text { the search tool. For example, earlier blood group and antibodies cannot be compared } \\
\text { with actual results for safety reasons }\end{array}$ \\
\hline & $\begin{array}{l}\text { Warning flag not updated or } \\
\text { removed in error }\end{array}$ & $\begin{array}{l}\text { IT user based error: Alert signs such as transfusion relevant antibodies are ignored, } \\
\text { not updated or accidently removed }\end{array}$ \\
\hline & $\begin{array}{l}\text { Computer or other IT } \\
\text { systems failure }\end{array}$ & $\begin{array}{l}\text { Errors related to computer system such as no access possibility due to crash, updates or } \\
\text { overhaul; errors related to electronic blood management system, access failure }\end{array}$ \\
\hline & Incorrect entry & $\begin{array}{l}\text { Incorrect or incomplete result or data entered or accessed manually, undetected or } \\
\text { uncorrected wrong operation (copy, paste, delete) }\end{array}$ \\
\hline & Blood order & $\begin{array}{l}\text { Blood issued against wrong patient ID (sample or request form), error originates from } \\
\text { electronic blood ordering system }\end{array}$ \\
\hline & Administrator related error & Erroneous combination of records in data base, deletion of data, etc. \\
\hline $\begin{array}{l}\text { Errors related to analog } \\
\text { documentation paper-based } \\
\text { forms/charts/documentation }\end{array}$ & $\begin{array}{l}\text { Paper documentation related } \\
\text { errors }\end{array}$ & $\begin{array}{l}\text { Unreadable, wrong chart, misplaced, not filed in chart, torn, lacking, incomplete content } \\
\text { etc. }\end{array}$ \\
\hline \multirow[t]{3}{*}{ Other equipment failure } & $\begin{array}{l}\text { Technical failure of used } \\
\text { equipment }\end{array}$ & $\begin{array}{l}\text { i.e. blood warming device for massive transfusion, blood gas analyzer, pressure device } \\
\text { for rapid infusion, clotting of leukocyte depletion filters, etc. }\end{array}$ \\
\hline & Wrong or no equipment & $\begin{array}{l}\text { Wrong or no equipment used, although available; monitoring, diagnostics, application } \\
\text { technology not used, although first choice in a clinical situations, such as blood filter } \\
\text { systems, plasmatherm for thawing of frozen blood components, hemoglobin analyzer } \leq\end{array}$ \\
\hline & Understaffing & Reports, in which the error mainly is attributed to a lack of personnel \\
\hline \multirow[t]{2}{*}{ Communication } & Subject to subject & $\begin{array}{l}\text { No or erroneous transmission of information from, i.e., surgeon to anesthesiologist, } \\
\text { transfusion specialist to blood bank, nurse to physician, transport service to medical } \\
\text { staff, etc. }\end{array}$ \\
\hline & $\begin{array}{l}\text { Subject and technique } \\
\text { including IT }\end{array}$ & $\begin{array}{l}\text { Missing or erroneous exchange of relevant information from operator, reader or user } \\
\text { to (hospital information system KIS, laboratory and monitoring IT or vice versa }\end{array}$ \\
\hline
\end{tabular}




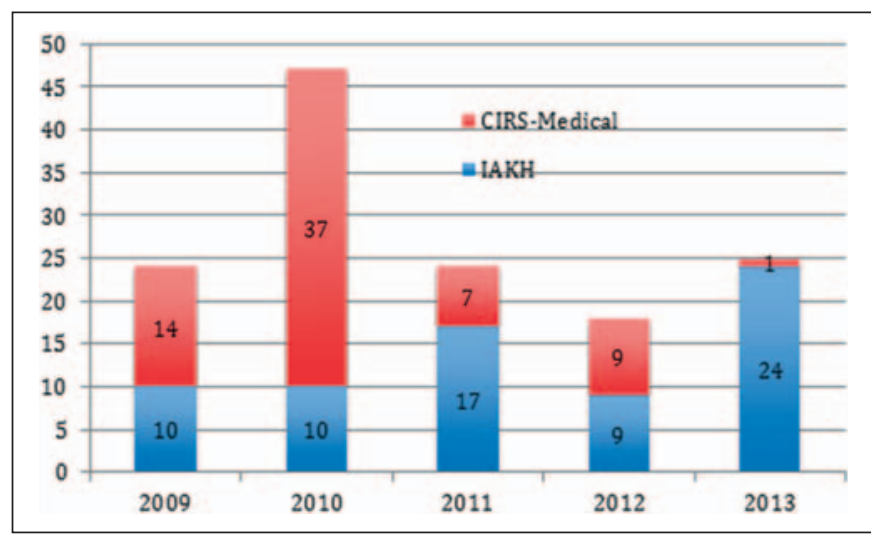

Fig. 1. Chronicle and data base source of the reports. Critical incidents in hemotherapy were reported into two affiliated databases - the CIRS-Medical of the German Associations of Anesthesiologists (DGAI and BDA) and the IAKH database. Except for 2010, round 24 incident reports were posted per year.

In an attempt to confirm the relevance of the critical incident to the reader, the expert group tried to estimate the frequency of the event in German practice with the help of published case reports and personal experience of committee members. Termed as 'frequency estimate', the estimated frequency of an error was classified according to the rate of serious adverse events of pharmaceutical drugs in approval studies as follows: extremely rare - 1:100,000, rare - 1:10,000, medium $-1: 1,000$, occasional $-1: 100$, frequent $-1: 10$. In a further attempt to categorize the potential risk for the recipient's integrity, which is also termed 'damage potency', the committee filed the error case in 5 damage groups from death risk to minor disabilities, similar to the serious adverse event grading in pharmaceutical approval studies: 1) no permanent or transient damage, 2) minor and/or weak transient damage, 3) minor and/or weak transient damage or light permanent disability, 4) considerable acute and/or considerable permanent disability, 5) death or permanent disability.

To assess the association between an erroneous blood administration process to the severity of pre-existing diseases, ASA physical statuses (perioperative risk stratification by the American Society of Anesthesiologists) were included in our analysis.

The committee edited and published each case on the IAKH website ( $w w w$. iakh.de) together with recommendations to avoid the error both by changes in the process organization of the reporting institution and by changes of the institutional structure. The structure quality comprises the use of other or modern equipment, the increase in personnel, the use of computer technology, the change of existing equipment by the manufacturer, or a change of existing laws and guidelines by the respective authorities. Expert risk minimization recommendations were made based on a committee discussion where the potency for hindrance is either logic, self-explanatory, or based on the experience and knowledge of the experts.

\section{Results}

During the 5-year period since the start in 2009, 138 cases were reported via IAKH and CIRS-AINS. More than half of cases (55.9\%) originated from the IAKH registry (fig. 1). The webpagebased anonymous entry of an incident is followed by a detailed assessment of the causes and an error analysis.

In more than as half of the reports (52.7\%), multiple errors in the application process could be identified. One report case contained $2.16 \pm 1.6$ errors (mean $\pm \mathrm{SD}$ ). Categories, numbers, and rates of reported errors are listed in table 3.

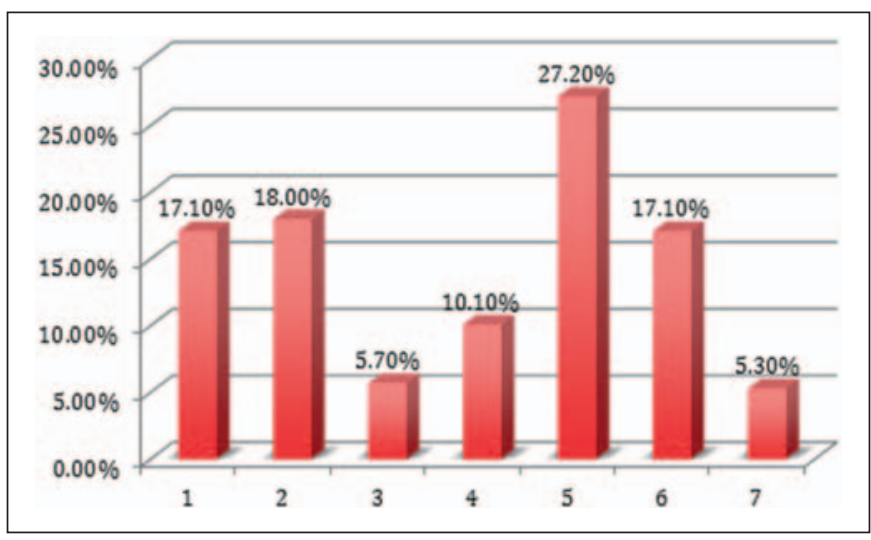

Fig. 2. Error location within the administration process chain. Errors were located in various steps of the blood product donation process. Process steps: 1) blood product order; 2) blood group sample withdrawal and tube labeling; 3) laboratory handling of blood probes, screen and type, release of ordered blood; 4) transport and handling of blood products, 5) blood product administration, 6) patient identification, 7) others such as coagulation management, autologous processing, or donation (see table 1 for comparison). The administration process itself was by far the most frequent source of errors.

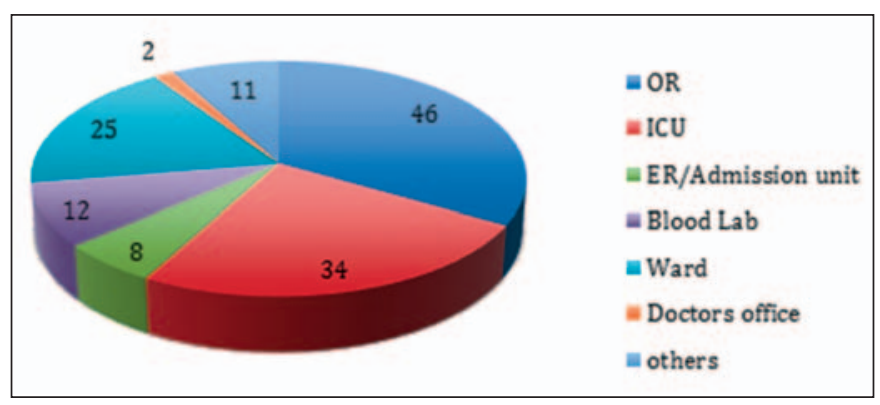

Fig. 3. Institutional location of errors. Incidents occurred in various locations and surroundings $(\mathrm{n}=138)$. However, from operating room $(\mathrm{OR})$ and intensive care unit (ICU), $70 \%$ of incidents were reported. ER = emergency room.

For all entries, the erroneous process step within the administration process was located (fig. 2). Thus, $5.3 \%$ of incidents occurred in steps beyond our predefined process steps, such as reports addressing surgical procedure and techniques, pre-donation, or blood product processing. In addition, in 135 cases, the functional unit in the medical institution could be located, i.e. the place where the error initiated (fig. 3). Most critical incidents occurred in operating rooms (OR) (34.1\%), intensive care units (ICU) (25.2\%) and peripheral wards $(18.5 \%)$, and to a more minor degree in the laboratory $(8.9 \%)$, emergency admission unit $(5.9 \%)$, private practice office $(1.5 \%)$ and others (e.g. recovery room of the blood donation unit 5.9\%).

Both, near misses and true mismatches were reported in our critical incident reporting system. As true errors, we categorized the actual transfusion of wrong blood to the right recipient or vice versa. Whenever the blood product was administered to the patient, the error qualified for a true error instead of a near miss. Thus, transfusion of compatible but confused blood to a recipient was not categorized as near miss. Near misses were all detected errors where, as a consequence, no administration of the blood prod- 
Table 3. Reported errors by category - number and rates

\begin{tabular}{|c|c|c|c|}
\hline Error category & Subcategory & $\begin{array}{l}\text { Number of } \\
\text { reports }\end{array}$ & $\begin{array}{l}\text { Rate of all } \\
\text { errors, \% }\end{array}$ \\
\hline \multirow[t]{5}{*}{ Avoidable, delayed or undertransfusion (no near misses) } & Avoidable, discarded / wasted blood products & 6 & 2.01 \\
\hline & Delayed & 22 & 6.15 \\
\hline & Overtransfusion / TACO & 9 & 3.02 \\
\hline & Undertransfusion & 3 & 1.01 \\
\hline & Coagulation management and dosing error & 20 & 6.71 \\
\hline Sum & & 60 & 18.6 \\
\hline \multirow{2}{*}{$\begin{array}{l}\text { Incorrect blood component transfused } \\
\text { For mismatches during actual administrations or near } \\
\quad \text { misses see table } 4\end{array}$} & Wrong kind of blood product transfused & 8 & 2.68 \\
\hline & Unmatched & 2 & 0.67 \\
\hline Wrong blood or recipient & Incompatible & 6 & 2.01 \\
\hline \multirow[t]{2}{*}{ Wrong blood or recipient } & & see table 4) & \\
\hline & Specific requirements for component not met & 1 & 0.34 \\
\hline Sum & & 47 & 15.8 \\
\hline \multirow[t]{3}{*}{ Errors related to preoperative donation or cell salvage } & Use and production of autologous products & 11 & 3.69 \\
\hline & Cell saver defect (technical) & 1 & 0.34 \\
\hline & $\begin{array}{l}\text { Mismatch of products following disconnection or confusion } \\
\text { of autologous products }\end{array}$ & 1 & 0.34 \\
\hline Sum & & 13 & 4.36 \\
\hline \multirow[t]{3}{*}{ Patient identification (ID) } & Screen and/or type test probe from wrong patient & 9 & 3.02 \\
\hline & Laboratory test or bedside test from wrong patient & 2 & 0.67 \\
\hline & Administration of blood / coagulation product & 5 & 1.68 \\
\hline \multicolumn{4}{|l|}{ Handling and storage errors } \\
\hline \multirow[t]{3}{*}{ Labeling } & Labeling of blood samples/probes/ tubes & 7 & 2.35 \\
\hline & Labeling of chart, blood order forms or other documents & 2 & 0.67 \\
\hline & Labeling of blood products / coagulation products /drugs & 5 & 1.68 \\
\hline \multirow[t]{2}{*}{ Laboratory } & $\begin{array}{l}\text { Laboratory/POCT error including result output and } \\
\text { pre-analytic errors }\end{array}$ & 10 & 3.36 \\
\hline & Testing error & 1 & 0.34 \\
\hline \multirow[t]{3}{*}{ Storage } & Storage errors & 4 & 1.34 \\
\hline & Temperature deviation & 3 & 1.01 \\
\hline & Component expiry & 1 & 0.34 \\
\hline Product release & Unit booking-off from depot or blood bank & 5 & 1.68 \\
\hline Transport & Transport error & 1 & 0.34 \\
\hline Sum & & 39 & 13.1 \\
\hline \multicolumn{4}{|l|}{ Administration error } \\
\hline Indication & $\begin{array}{l}\text { Indication for transfusion erroneous due to lab or } \\
\text { preanalytic error, missing guideline coverage etc. }\end{array}$ & 8 & 2.68 \\
\hline \multirow[t]{4}{*}{ Blood management } & Uncorrected preoperative anemia & 1 & 0.34 \\
\hline & Transfusion trigger unrecognized & 5 & 1.68 \\
\hline & Urgency of blood use & 3 & 1.01 \\
\hline & Volume status assessment related to transfusion & 6 & 2.01 \\
\hline Consent & Informed consent not done & 1 & 0.34 \\
\hline Blood order & $\begin{array}{l}\text { Blood order error (missed, incorrect, wrong patient, } \\
\text { missing data) }\end{array}$ & 5 & 1.68 \\
\hline \multirow[t]{2}{*}{ Bedside test } & Bedside test not done & 1 & 0.34 \\
\hline & Bedside test wrongly interpreted / wrongly done & 4 & 1.34 \\
\hline
\end{tabular}


Table 3. Continued

\begin{tabular}{|c|c|c|c|}
\hline Error category & Subcategory & $\begin{array}{l}\text { Number of } \\
\text { reports }\end{array}$ & $\begin{array}{l}\text { Rate of all } \\
\text { errors, \% }\end{array}$ \\
\hline \multirow[t]{7}{*}{ Preparation of transfusion procedure administration } & Type and Screen, crossmatch & 6 & 2.01 \\
\hline & Pretransfusion procedure & 12 & 4.03 \\
\hline & Timing & 5 & 1.68 \\
\hline & Delegation of transfusion & 2 & 0.67 \\
\hline & Screening test result expiry & 2 & 0.67 \\
\hline & $\begin{array}{l}\text { Multiple transfusion processes for various patients } \\
\text { synchronously or massive transfusion as contributing factor }\end{array}$ & 9 & 3.02 \\
\hline & Double unit administration & 3 & 1.01 \\
\hline Monitoring & Monitoring during administration & 1 & 0.34 \\
\hline Documentation & Documentation of administration & 1 & 0.34 \\
\hline Sum & & 75 & 25.2 \\
\hline \multicolumn{4}{|l|}{ Errors related to IT } \\
\hline & Wrong record selected & 0 & 0 \\
\hline & Failure to consult or identify historical record & 1 & 0.34 \\
\hline & Warning flag not updated or removed in error & 0 & 0 \\
\hline & Computer or other IT systems failure & 1 & 0.34 \\
\hline & Incorrect entry & 2 & 0.67 \\
\hline & Electronic blood order & 3 & 1.01 \\
\hline & Administrator/system related error & 0 & 0 \\
\hline Sum & & 7 & 2.35 \\
\hline $\begin{array}{l}\text { Errors related to analog documentation paper based } \\
\text { forms/charts/documentation }\end{array}$ & Unreadable, wrong chart, etc. & 4 & 1.34 \\
\hline Sum & & 4 & 1.34 \\
\hline \multirow[t]{3}{*}{ Other equipment failure } & Technical failure of used equipment & 4 & 1.34 \\
\hline & Wrong use of equipment or no equipment & 5 & 1.68 \\
\hline & Understaffing & 3 & 1.01 \\
\hline Sum & & 12 & 4.03 \\
\hline \multirow[t]{2}{*}{ Communication } & Subject to subject (interindividually/interinstitutionally) & 20 & 6.71 \\
\hline & Subject and technique including IT, laboratory and monitoring & 5 & 1.68 \\
\hline Sum & & 25 & 8.39 \\
\hline Total sum & & 298 & 100 \\
\hline
\end{tabular}

uct to the patient had been occurred. For mismatch of recipient and blood product (wrong blood for right patient or wrong patient for wrong blood, near misses (46\%) and true errors (53\%) are given as absolute numbers in detail (table 4).

Identification of concerned blood products was possible in all cases. Blood type testing errors were assigned to red cell transfusion only. The administration error applied in $63 \%$ to packed red cells, in $17 \%$ to coagulation concentrates (eventually more if the reporting form for coagulation mismanagement would be active from the start in 2009 , but this was set up in 2013), and in $11.6 \%$ to autologous products (pre-donation and cell salvage). Fresh frozen plasma and platelets played a minor role (3.9\% and 3.1\%, respectively) (fig. 4).

ASA classification of (intended) recipients was ASA III (46.3\%) and IV (23.2\%); minor groups were ASA II (17.1\%), V (8.5\%). and I (4.9\%) (fig. 5).

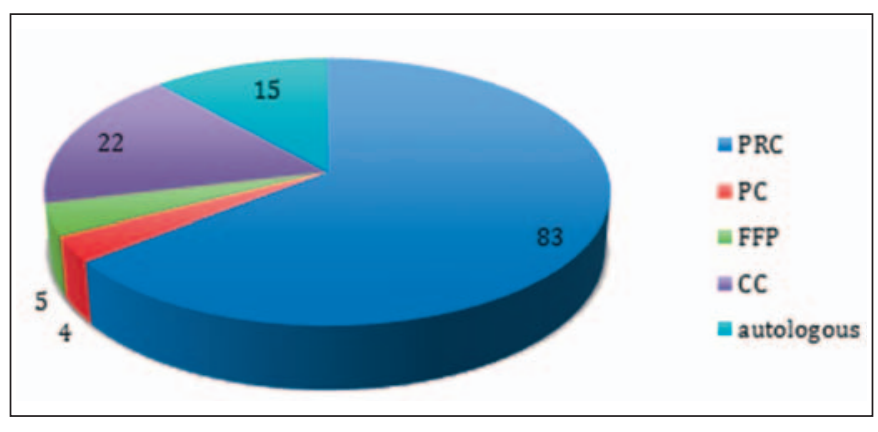

Fig. 4. Blood product concerned. Administration incidents of all existing blood products were reported with the predominance of packed red cells ( 83 out of 129 reports). Nine reports were not referring to a specific product. The number of critical incidents for autologous product seems relatively high. PRC $=$ Packed red cells; $\mathrm{PC}=$ platelet concentrates; FFP = fresh frozen plasma; $\mathrm{CC}=$ coagulation factor concentrate. 


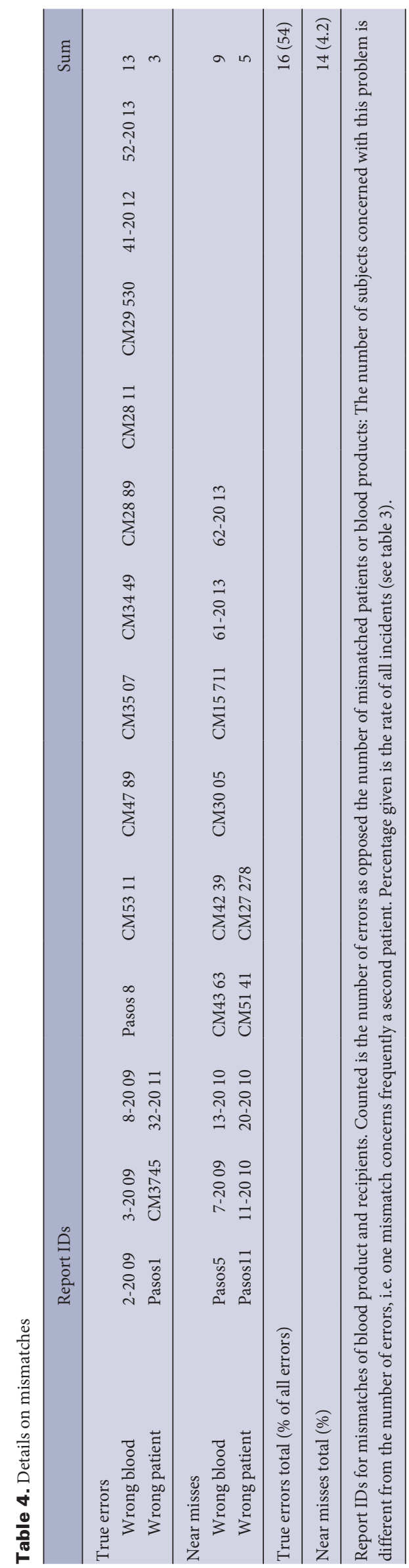

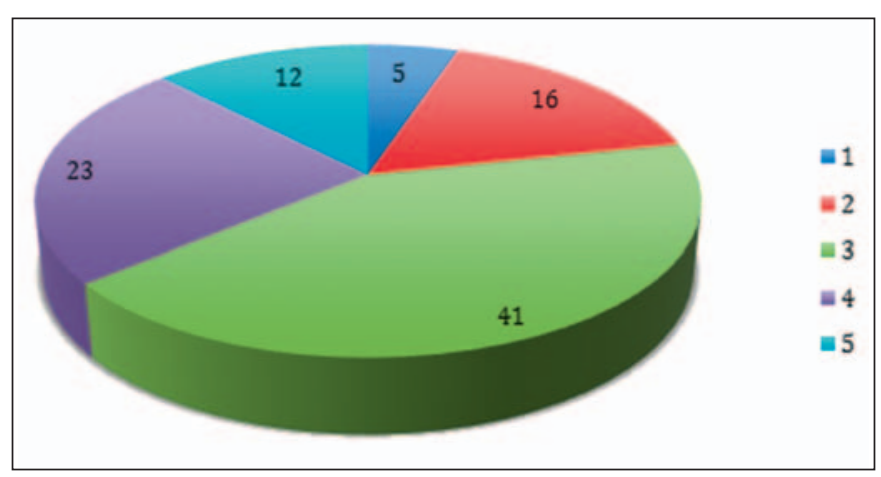

Fig. 5. ASA classification concerned. Incidents occurred in transfusion processes for all -from healthy to severely ill recipients (indicated by ASA physical status classification system), with a clear majority in ASA 3 (by definition patients with a severe systemic disease) and in ASA 4 (severe systemic disease that is a constant threat to life). Since the information of the ASA status is not obligatory in the report forms, 41 cases were not reported.

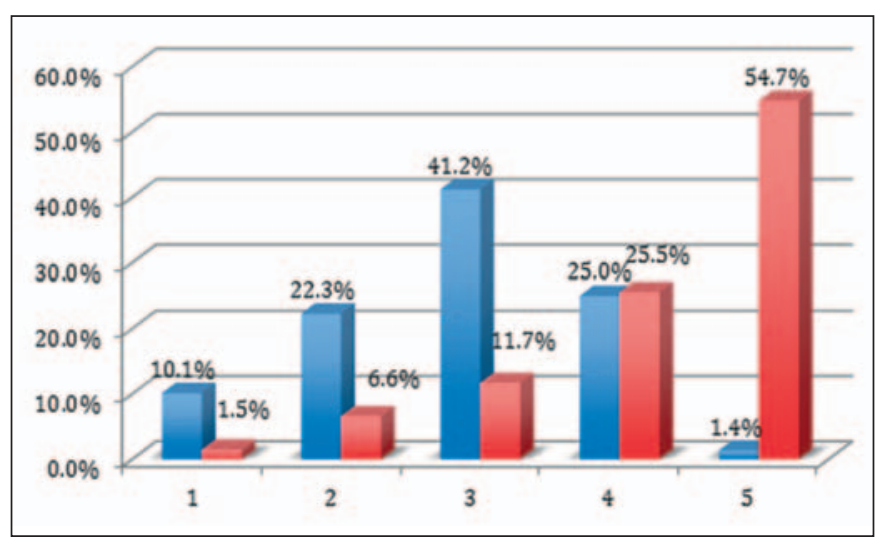

Fig. 6. Frequency and risk of damage estimate. Reported incidents were more than rare and inherited the risk of death for the recipient. Estimated frequency (blue columns) of reported critical incidents were classified by the experts as 1 ) extremely rare - 1: 100,000,2) rare - 1:10,000,3) medium - 1:1,000,4) occasional $-1: 100,5)$ frequent $-1: 10$. The percentage of reports that was located in that classification is given on top of the column. The potential to harm the recipient (red columns) was classified as 1) No permanent or transient damage, 2) minor and/or weak transient damage, 3) minor and/or weak transient damage or light permanent disability, 4) considerable acute and/or considerable permanent disability, 5) death or permanent disability.

Estimated frequency of critical incidents was 1:10,000 (21\%), 1: $1,000(43 \%)$, and 1:100 (25\%) (fig. 6). Potential damage was mostly death or permanent disability in $58 \%$ of reports, considerable acute damage or considerable permanent disability in $25 \%$, and minor and/or weak transient damage or light permanent disability in $13 \%$ (fig. 6).

\section{Process Quality}

Critical incidents occurred in $35.5 \%$ of reported cases in a routine situation (35.5\%), in $14 \%$ in emergency situations, and in $21 \%$ during irregular work hours at nighttime or weekends (fig. 7). Staff involved in education or only temporary at work was associated to the error in $10.2 \%$. Miscommunication or incomplete information 
transfer as a major source of errors could be identified in $19.4 \%$. However, communication errors among patients, health care personnel (physicians, nurses, ambulance drivers) and institutions (laboratory, wards, ICU, emergency department, OR) were an associated factor that played a role in the development of the incident in 55\% of reported cases. Also the erroneous transmission of wrong or incomplete datasets of patients, blood orders, or blood products was defined as communication error. Only in 2 cases, the incidents were caused by acts of negligence. In total, team conflicts were obvious in 4 cases.

Indication of administration of blood products frequently was not in congruence with the existing cross-sectional guidelines for

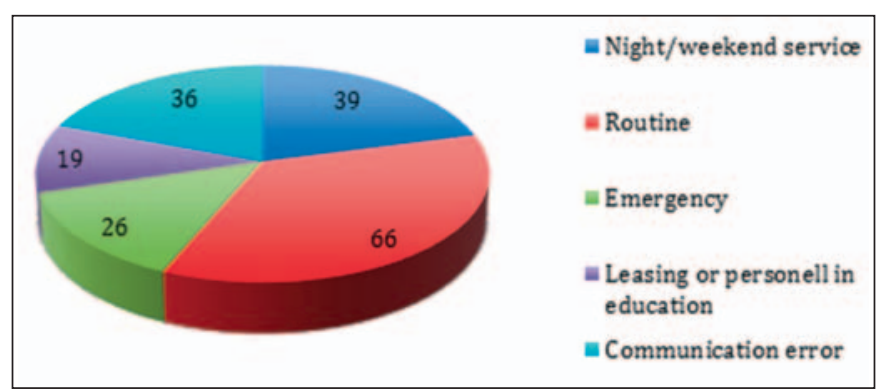

Fig. 7. Circumstances and contributing factors. Incidents mainly occurred under routine circumstances. Emergency situation was a contributing factor only in $26 \%$. For some reports, more than one contributing factor could be identified. the use of blood and blood products as set by the German Medical Association [9]. It was correct in $29.0 \%$ but incorrect in $36.2 \%$; for the rest of reports $(34.8 \%)$, there were no indication if the given guidelines were followed or not.

Confusions and mismatches as well as wrong dosages of blood products occurred in almost half of all reports (67 times in 138 reports, $48.6 \%$ ) (fig. 8). Of all mismatches, blood product confusion contributed to $18.8 \%$, patient confusion to $8.7 \%$, and probe mismatch to $7.3 \%$. Wrong doses of blood or coagulation factors were applied in $13.8 \%$.

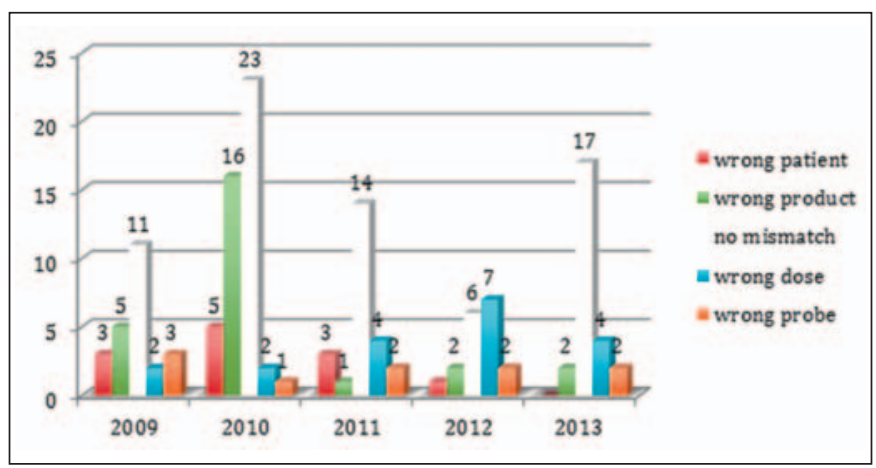

Fig. 8. Confusion and mismatches, wrong doses. Incidents reported mismatches of blood product, of patients, and of patients. Also, administration of blood products in wrong dosage (according to efficacy or guidelines). White columns indicate incidents other than mismatch or wrong dosage.

Table 5. Survey of committee's recommendations for structure quality

\begin{tabular}{|c|c|c|}
\hline Structure improvement by & Number & $\begin{array}{l}\text { Percentage of all } \\
\text { recommendation }\end{array}$ \\
\hline Emergency box of a collection of blood and blood products for trauma and massive bleeding incl. sampling tubes & 5 & 1.57 \\
\hline $\begin{array}{l}\text { Establishment of clinical hemotherapy pathways }{ }^{\star} \text { for patient blood management, bridging of coumarins and } \\
\text { new oral anticoagulants, or for emergency revision surgery }\end{array}$ & 9 & 2.82 \\
\hline Central coagulation and hemostasis consultant emergency phone & 8 & 2.51 \\
\hline Staining dye for e.g. heparin that avoids confusion with another drug & 6 & 1.88 \\
\hline Central IT registry for patients with multiple antibodies & 2 & 0.63 \\
\hline Establish or install backup for defect POCT in OR, ICU (blood gas, coagulation, hemoglobin) & 13 & 4.08 \\
\hline IT controlled storage and software check for the availability of blood products in the storage & 3 & 0.94 \\
\hline Establish or use blood volume monitor (cardiac output and ejection fraction variability) & 8 & 2.51 \\
\hline $\begin{array}{l}\text { ID wrist bands for patient identification / scanner based ID check, bar code scanner for the administration of } \\
\text { drugs and blood products }\end{array}$ & 17 & 5.33 \\
\hline ID identity and compatibility check of blood product, probe and patient & 18 & 5.64 \\
\hline $\begin{array}{l}\text { Communication / compatibility of PDMS, laboratory and blood banking software (e.g. for plausibility check, } \\
\text { also for documentation of a single patient history for all disciplines within the institution, match of type } \\
\text { and screen with selected product, warning sign for drug orders and decreased liver or kidney function, } \\
\text { documentation of type and screen test result, actual match of estimated blood loss with actual blood loss } \\
\text { calculated from hemoglobin content) }\end{array}$ & 48 & 15.05 \\
\hline $\begin{array}{l}\text { IT control of electronic blood product and coagulation product order, feedback of blood product availability in } \\
\text { storage, automated blood product order for blood loss surgery, indication check and match with guidelines, }\end{array}$ & 27 & 8.46 \\
\hline
\end{tabular}


Table 5. Continued

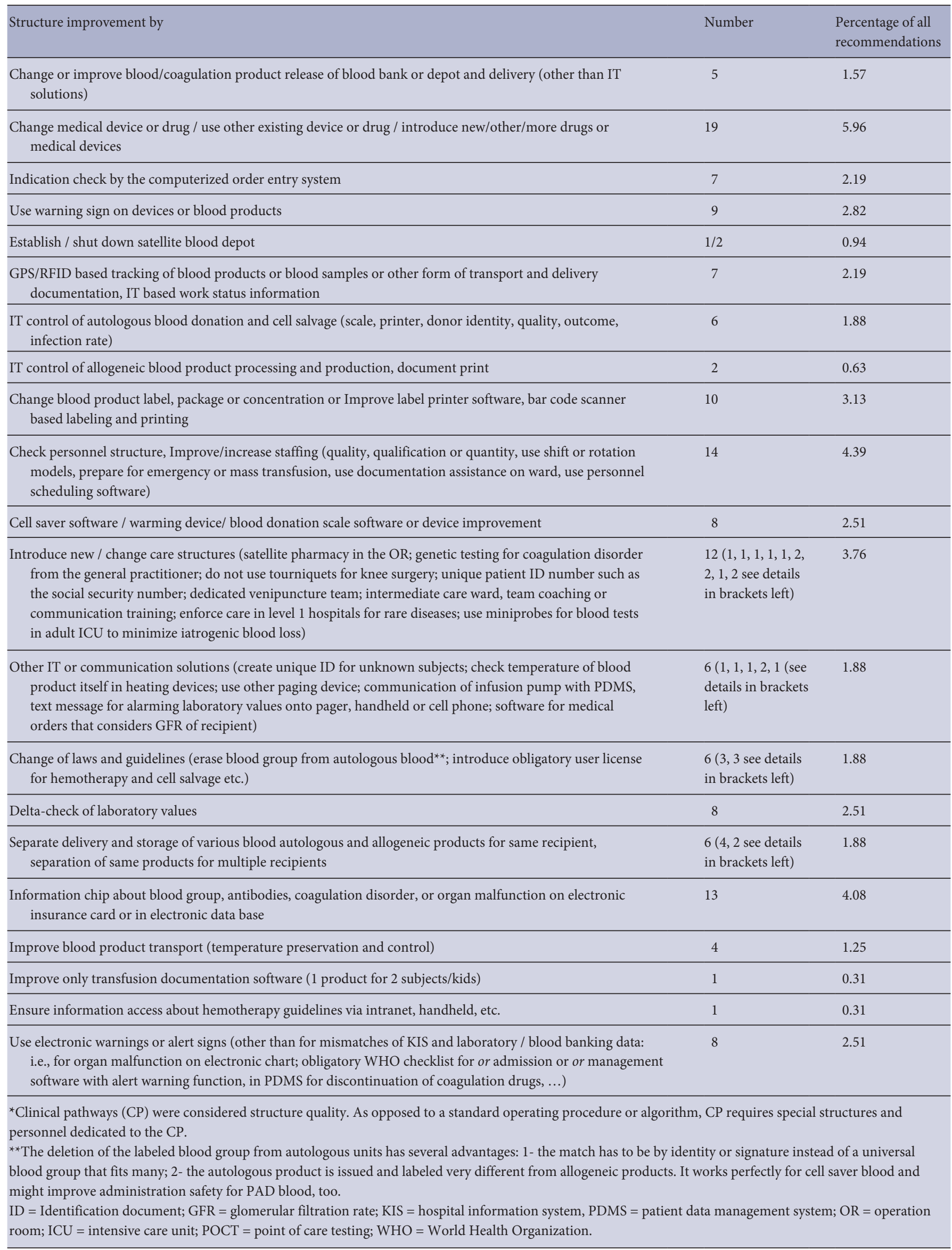


Recipient's identity match to the blood group detected by obligatory BST (mostly done only for ABO without D) was tested with respect to its capability to avoid the incident reported or to detect a mismatch of either patient or blood unit. Such kind of errors were detected by BST in only $1.8 \%$. BST was unable to avoid the reported mismatch in $29.7 \%$ or would have detected the confusion in $13.8 \%$. BST was effective to avoid the confusion of a patient, blood sample, or product in $2.6 \%$ and would be suitable to detect it in $5.8 \%$. However, it failed to avoid $66 \%$ of the incidents that have occurred. BST was performed in $96 \%$ of all reported administrations. It was done or interpreted wrongly in 4 of 142 cases. In 2 cases, the correct result did not come to the attention of the administrator, and once the BST was taken from the wrong patient. In 4 cases of identical ABO blood types, the BST was done but was unable to detect the error.

Administration process performance might be improved by detailed task descriptions ('How is the task to be done in that institution, step by step?') and standard operating procedures (SOPs) available for the field of hemotherapy. The committee gave 479 (3.7 \pm 0.6 per report) recommendations to improve administration process quality in total. Among those were 151 ( $1.27 \pm 0.5$ per report) collective staff educational measures such as round tables, team coaching, lectures or clinic information events on a specific topic per report, and simulation training. Moreover, to create a permanent change, 214 (1.74 \pm 0.5 per report) recommendations targeted to the establishment of a SOP, a written task description, or an algorithm. The measure to bring the report to the knowledge of the institutional transfusion committee was recommended in almost every case (and excluded from the listed recommendations in table 5).

\section{Structure Quality}

Secondary to procedural aspects, safety of blood product administration processes is also dependent on the structure of the institution. Resources that may play a role are understaffing, equipment deficiency, and technical outdated data management. The latter has a potential to control the administration process if used as an obligatory measure. The committee addressed administration-associated structure 319 (2.6 \pm 0.7 per incident $)$ times. An IT solution (almost exclusively software replacement) had most likely avoided the critical incident 189 times ( $1.6 \pm 0.4$ per report).

\section{Discussion}

In summary, during the first 5 years of the registry, two error reports per month had been registered and discussed by the expert committee. This analysis predominantly aimed at the nature of the incidents, and not at the number . Obviously, the results of this 5 -year review of a national CIRS specialized in hemotherapy must be interpreted very cautiously. In contrast to the voluntary hemovigilance study in the UK (SHOT - Serious Hazards of Transfusion Hemovigilance System) [12] which includes all participating health institutions in the UK, the IAKH voluntary web-based error registry cannot be used as a solid hemovigilance system. On the other hand, the German hemovigilance database of the PEI is not capable of giving information about non-fatal incidents as only transmission of infections, immunological transfusion reactions and transfusion-related acute lung injuries (TRALIs) have to be reported. There was no obligation until 2012 to report confusions or mismatches of blood products if they did not result in a lethal incompatibility reaction. Due to the lack of an obligation to report a critical incident to the IAKH error registry, the registry cannot be used to detect the absolute number of transfusion errors in Germany. Frequency estimates (fig. 6) given by the committee aim to demonstrate whether or not the reported incident is clinically relevant. To evaluate the benefit of these recommendations, further evaluations would be needed, e.g. comparison of the numbers of incorrectly labeled blood samples or comparison of patient misidentification before and after the implementation of risk minimization measures. However, a scientifically sound interpretation of the expert recommendation's efficacy is difficult and therefore remains speculative.

It is possible to evaluate cofactors such as disease severity or complexity of treatment given (e.g., ASA physical status (fig. 5), emergency transfusion, night call or untrained staff (fig. 7)) using the IAKH error registry, and the data obtained resembles those of administration statistics of blood products in Europe in general (for ASA status see [13]). However, two-thirds of errors happened during routine work hours and under regular conditions. This underlines the significance of improving routine administration since work processes under regular conditions can be better controlled and standardized.

Coagulation management-associated errors might be more important as reflected by our results since the special entry form to report such an error was added later. Furthermore, recommendations of experts for risk minimization cannot be considered valid tools to avoid such transfusion errors. However, any tool to improve patient safety is based on the exchange of methods and measures to avoid risks.

What can be concluded, however, is that the frequency and the variety of errors when administrating blood or blood products are much higher than with other drugs [14]. It appears that product safety is by far superior to administration safety. Moreover, it becomes obvious that all possible errors can actually occur every time and for every aspect of the transfusion process as was previously suspected. This circumstance is worrying for both recipients and physicians and thwarts the sense of a possibly false security generated by the presence of the strict German transfusion law with updated evidence based cross-sectional guidelines for the use of blood and blood products [9]. The question arises if administration safety can be guaranteed by laws, guidelines, code of conduct rules, obligatory reports to PEI every year, and the obligation for physicians to act in a prudent manner. The implementation of guidelines is delayed and incomplete [15], and the resistance to change daily practice should not be underestimated. Moreover, such an implementation is influenced by various interests at many different levels [16]. However, the knowledge of the frequency and variety of errors might contribute to overcome current implementation barriers. In this respect, the results of this analysis are of general interest. 
In addition, the knowledge what causes an error might be used to develop strategies to avoid it. It is the opinion of the committee that a considerable part of the reported errors could be eliminated by changes of administration or IT solutions and eventually the implementation of strict SOPs (see three case reports and the respective recommendation for avoidance in the Amendment at http://content.karger.com/ProdukteDB/produkte.asp?doi= 453320). Although the latter approach might be less effective in emergency situations, it should be kept in mind that the majority of reported incidents occurred in a routine situation, and, due to their compact and short form, the adherence to SOPs might be higher than that to laws or detailed guidelines [16]. However, even after implementation of SOPs the need for continued education of all faculty members remains. According to a recent prospective study, the 'training methods varied with most perceived to have minimal effectiveness' [17]. In this respect it is worth mentioning that almost 500 committee recommendations for 138 incidents (3.7 per incident) address improvements of education and process quality.

Another aspect of this analysis was to evaluate whether or not common techniques assumed to be crucial and effective, e.g., BSTare effective in avoiding transfusion errors. According to the results of the IAKH registry, BST was able to avoid the mismatch in only $2.6 \%$. Most errors reported (66\%) were unaffected by the BST although major incompatibility transfusion is still possible. Greinacher [4] retrospectively determined $50 \%$ of confusions occurring between BST and transfusion (16 of 32 cases). Thus there is reasonable suspicion that BST is overestimated in its efficacy to avoid confusions. BST fails if the probe for cross-match is flawlessly taken not from the recipient but from another person, if the recipient's identity is falsified but has the same blood group as the ID holder, if the BST is not done or misinterpreted, or if the match of blood groups and paperwork is done correctly but the transfusion started to an untested wrong recipient. This demonstrates that BST does not or only very marginally obviate handling errors such as a flawless comparison of $\mathrm{ABO}$ bedside results with all documents completed as well as with the products ready for transfusion. Moreover, it addresses only part of all administration safety issues. Based on this error analysis, the question arises if BST is worth the minimal cost as in most of the error reports it was ineffective as $66 \%$ of incidents were unchanged by the test result. In those reports concerned, the test was misinterpreted, was not done, the recipient was confused after performance of the test, or the wrong blood product was used for the test. The knowledge of the limitations of the BST should be kept in mind by administrators of red blood cells in Germany.

Technical solutions in general might be more effective since they both can lead the user through guideline-compliant administration of blood products and control the administration process [18]. Special IT-based safety features are proposed to erase user errors, e.g., the use of bar codes [19] and radiofrequency identification (RFID) tracking systems [20-22] from blood sampling to transfusion [23]. Using a computerized administration guide, the documentation of drug and blood administration can be improved.
In a lot of German institutions blood product order via phone or paper forms is still active, not allowing a plausibility check and the data match to the patient's chart information and laboratory results. When considering the technical equipment of German hospitals, improvement of IT-based measures might a very promising approach to increase hemovigilance in Germany. However, current publications emphasize the potential of an end-to-end-control of blood product administration since SHOT lessons teach us that 'the main risks remain human factors' [12]. The suggestions by the IAKH committee comprised procedures - to mention only the most frequent recommendations - such as the delta check method of the laboratory software to detect implausible laboratory values or the compatibility of blood banking software with the institutional patient data management system (PDMS). Procedures and techniques not yet applied in Germany rarely were suggested by the committee, e.g. a central registry for patients with multiple antibodies (twice in table 4 ) as already recommended by Delaney and coauthors [24].

The most frequent suggestion ( $15 \%$ of all recommendations) of the expert committee was to establish compatible IT system for blood banking and PDMS. In the opinion of the committee, this change inherits the potential to avoid transfusion errors in multiple cases. On the other hand, it depicts a major problem in the IT structure of German transfusion medicine - the majority of blood banking software systems is incompatible with the PDMS of the treatment facilities. As a consequence, double data entry and double input errors occur, and information transfer and plausibility checks are missed. User errors remain undetected. The safety improvement with the implementation of compatible systems seems to be underestimated. The Eurocode International Blood Labeling System provides a quick solution. To date, the unique product ID, product type, and blood group are encoded eye-readable and in three linear barcodes at the product label but in the near future, the Eurocode system will provide a threefold match in one two-dimensional barcode format. The computer-generated match of data matrix and thus blood product information can easily be read in the PDMS by scanner cameras [25].

In addition, other IT-associated measures that more or less are based on the data management systems already in use were recommended, such as the electronic order of blood products [26] and identification checks $[27,28]$.

However, the question remains whether or not IT solutions will be able to increase the safety and performance in real practice. Current attempts to improve user performance by directing administration procesess and decision steps via computed guidance can be bypassed in some instances [29]. So it is questionable if a computer-guided order entry can be designed for better performance. Liberal practice is also reported elsewhere [30-32]. Therefore, the recommendation to establish an electronic order system is based on many theoretical but yet unproven advantages, such as adherence to guidelines, plausibility checks, data control, documentation, and storage-associated issues such as procurement. However, first attempts in Stanford, CA, and Minneapolis, MN, to install clinical decision support were promising [33-36]. 
Among the IT solutions most frequently suggested by the committee (listed in table 1) was the scanner-based guided identification match from patient $[37,38]$, blood sample $[39,40]$, and blood products - the 'vein-to-vein' IT system. Its importance and potential benefit has only recently been proven [22, 41]. Mismatches in $1 \%$ of transfusion processes could be avoided by using a scannerbased system [19], although its implementation is not free of complications [42]. Even though this system or parts of it are tested by several institutions, only a few experienced users worldwide currently are using it today $[43,44]$. Furthermore, its implementation is often restrained by the national data protection guidelines/laws. The present report, however, demonstrates the urgency to use and further develop those systems [27, 43, 45-52] in order to markedly improve patient safety in spite of unsolved data safety issues. Encoding techniques still could be added and improved in the second implementation phase, but the benefit of a scanner-based system seems to be beyond question when considering the variety of incidents summarized in this report. Whether or not the technical refinement of vein-to-vein IT systems should be awaited before implementation is a matter of controversial debate. However, a number of problems are still unsolved, e.g., the choice of frequency and interference effects when applying RFID technology [22, 53-55]. Lastly, when considering the German hemovigilance report [3], it becomes obvious that administration safety is not well reported in Germany. The relation of In the IAKH registry, the erroneous administration of the wrong blood product to the wrong patient was reported as 'near misses' 14 times (nearly 10\% of reports) even though the product had actually been administered. The actual rate of nationwide confusions is not known but clearly is much higher than the reported deaths due to transfusion errors. The ABO incompatibility frequency in Germany resulting in serious transfusion reactions amounts to $6.8 \%$ of all reported serious transfusion reactions per year (data from 1999 until 2009 [56]). To restrict the safety of blood administration onto fatalities might arouse patient safety concerns - especially when technical solutions to the problem are available and inexpensive, at least when compared to further reduction of infection transmission rates.
In summary, the analysis of errors occurring in the German transfusion system showed that BST covered only a minority of handling errors, that the adherence to the extensive German transfusion guidelines (particularly with regard to transfusion needs) is low, and that, according to the expert recommendations for practice improvement, transfusion safety might be improved by technical solutions such as barcode- or RFID-based scanner techniques.

\section{Supported by}

IAKH e.V., German Interdisciplinary Task Force for Clinical Hemotherapy DIVI, German Interdisciplinary Association for Critical Care and Emergency Medicine, Section Hemotherapy and Hemostaseology

DGAI, German Society for Anesthesiology and Critical Care Medicine BDA, Association of German Anesthesiologists.

\section{Amendment}

See supplemental material at http://content.karger.com/ProdukteDB/ produkte. asp? doi $=453320$.

\section{Acknowledgments}

Prof. Dr. Volker Kretschmer founded the DIVI section for hemotherapy and hemostaseology. In this section, he planted the idea and organized and inaugurated this registry.

Dr. Arnulf Weiler-Lorentz constructed the entry forms and the connected data base.

The IAKH funded the remodeling and further development of the registry as well as this article.

We especially thank all current and previous committee members for their excellent work and for devoting their time, ideas, and thoughts.

\section{Disclosure Statement}

All authors state that there is no conflict of interests.

\section{References}

1 Gesetz zur Regelung des Transfusionswesens (Transfusionsgesetz) in der Fassung der Bekanntmachung vom 28. August 2007 (BGBl. I S. 2169), zuletzt geändert durch Gesetz vom 17. Juli 2009 (BGBl. I S. 1990), pp 11.

2 Bundesärztekammer (German Medical Association) Cross-Sectional Guidelines for Therapy with Blood Components and Plasma Derivatives. 4th ed. www. bundesaerztekammer.de/fileadmin/user_upload/downloads/Querschnittsleitlinie_Gesamtdokument-englisch_ 07032011.pdf (last accessed February 15, 2017).

3 Funk M, Lohmann A, Spranger R: Hemovigilance Report of the Paul-Ehrlich-Institut 2013/2014. Assessment of the Reports of Serious Adverse Transfusion Reactions pursuant to Section 63i AMG (German Medicines Act). www.pei.de/SharedDocs/Downloads/ vigilanz/haemovigilanz/publikationen/haemovigilancereport-2013-2014.pdf?__blob=publicationFiled $v=6$ (last accessed February 15, 2017)
4 Greinacher A: Technik der Bluttransfusion; in Mueller-Eckhadrdt C, Kiefel V (eds): Transfusionsmedizin. Heidelberg, Springer, 2003, pp 329-337.

5 Caspari G, Alpen U, Greinacher A: The risk of transfusion to the wrong patient in Germany. Transfusion 2002;42:1238-1239.

6 Linden JV, Wagner K, Voytovich AE, Sheehan J: Transfusion errors in New York State: an analysis of 10 years' experience. Transfusion 2000;40:1207-1213.

7 Frietsch T, Weiler-Lorentz A, Schipplick M, Kretschmer V: The interdisciplinary work community for clinical hemotherapy start SHOT for a German haemovigilance system. Anasthesiol Intensivmed Notfallmed Schmerzther 2009;44:626-628.

8 IAKH Foundation in February 2002. Dtsch Arztebl 2003;100:A-286 / B-254 / C-246.
9 German Association of Physicians: Cross-Sectional Guidelines for Therapy with Blood Components and Plasma Derivatives. Transfus Med Hemother 2009;36: 347-481.

10 Frietsch T, Auswertekommission CID: CIRS transfusion report 2009. Anasthesiol Intensivmed 2011;52: 106-111.

11 Berufsverband Deutscher Anästhesisten, Deutsche Gesellschaft für Anästhesiologie und Intensivmedizin Ärztliches Zentrum für Qualität in der Medizin: CIRSAINS. www.dgai.de/projekte/cirs-ains (last accessed February 15, 2017)..

12 Bolton-Maggs PH, Cohen H: Serious hazards of transfusion (SHOT) haemovigilance and progress is improving transfusion safety. Br J Haematol 2013;163: $303-314$ 
13 Meier J, Filipescu D, Kozek-Langenecker S, Llau Pitarch J, Mallett S, Martus P, Matot I: Intraoperative transfusion practices in Europe. Br J Anaesth 2016;116: 255-261.

14 Lau FY, Cheng G: To err is human nature. Can transfusion errors due to human factors ever be eliminated? Clin Chim Acta 2001;313:59-67.

15 Napolitano LM, Kurek S, Luchette FA, Corwin HL, Barie PS, Tisherman SA, Hebert PC, Anderson GL, Bard MR, Bromberg W, Chiu WC, Cipolle MD, Clancy KD, Diebel L, Hoff WS, Hughes KM, Munshi I, Nayduch D, Sandhu R, Yelon JA: Clinical practice guideline: red blood cell transfusion in adult trauma and critical care. Crit Care Med 2009;37:3124-3157.

16 Bosse G, Breuer JP, Spies C: The resistance to changing guidelines - what are the challenges and how to meet them? Best Pract Res Clin Anaesthesiol 2006;20:379395

17 Heddle NM, Fung M, Hervig T, Szczepiorkowski ZM, Torretta L, Arnold E, Lane S, Murphy MF: Challenges and opportunities to prevent transfusion errors: a Qualitative Evaluation for Safer Transfusion (QUEST). Transfusion 2012;52:1687-1695.

18 Nuttall GA, Stubbs JR, Oliver WC Jr: Transfusion errors: causes, incidence, and strategies for prevention. Curr Opin Anaesthesiol 2014;27:657-659.

19 Askeland RW, McGrane S, Levitt JS, Dane SK, Greene DL, Vandeberg JA, Walker K, Porcella A, Herwaldt LA, Carmen LT, Kemp JD: Improving transfusion safety: implementation of a comprehensive computerized bar code-based tracking system for detecting and preventing errors. Transfusion 2008;48:1308-1317.

20 Briggs L, Davis R, Gutierrez A, Kopetsky M, Young K, Veeramani R: RFID in the blood supply chain - increasing productivity, quality and patient safety. J Healthc Inf Manag 2009;23:54-63.

21 Chao C, Jen W, Chi Y, Lin B: Improving patient safety with RFID and mobile technology. Int J Electr Healthcare 2007;3:175-192.

22 Dzik WH: Technology for enhanced transfusion safety. Hematology Am Soc Hematol Educ Program 2005: 476-482.

23 Bolton-Maggs PH, Wood EM, Wiersum-Osselton JC: Wrong blood in tube - potential for serious outcomes: can it be prevented? Br J Haematol 2015;168:3-13.

24 Delaney M, Dinwiddie S, Nester TN, Aubuchon JA: The immunohematologic and patient safety benefits of a centralized transfusion database. Transfusion 2013; 53:771-776.

25 Knels R, Schnurstein K, Redecker-Klein A, Hiller J: Labeling of blood products with eurocode. Anasthesiol Intensivmed 2011;52:119-123.

26 Moore SB, Foss ML: Ordering blood for the wrong patient - getting inside the minds of ordering physicians. Mayo Clin Proc 2003;78:1337-1339.

27 Sandler SG, Langeberg A, Dohnalek L: Bar code technology improves positive patient identification an transfusion safety. Dev Biolog (Basel) 2005;120:19-24.
28 Lau FY, Wong R, Chui CH, Ng E, Cheng G: Improvement in transfusion safety using a specially designed transfusion wristband. Transfus Med 2000;10:121124.

29 Hibbs SP, Noel S, Miles D, Staves J, Murphy MF: The impact of electronic decision support and electronic remote blood issue on transfusion practice. Transfus Med 2014;24:274-279.

30 Norgaard A, De Lichtenberg TH, Nielsen J, Johansson PI: Monitoring compliance with transfusion guidelines in hospital departments by electronic data capture. Blood Transfus 2014;12:509-519.

31 Murphy DJ, Pronovost PJ, Lehmann CU, Gurses AP, Whitman GJ, Needham DM, Berenholtz SM: Red blood cell transfusion practices in two surgical intensive care units: A mixed methods assessment of barriers to evidence-based practice. Transfusion 2014;54: 2658-2667.

32 Oddason KE, Gudbjartsson T, Gudmundsson S, Karason S, Hreinsson K, Sigurdsson GH:Inappropriate use of blood components in critical care? (in Icelandic). Laeknabladid 2014;100:11-17.

33 McKinney ZJ, Peters JM, Gorlin JB, Perry EH: Improving red blood cell orders, utilization, and management with point-of-care clinical decision support. Transfusion 2015;55:2086-2094.

34 Goodnough LT, Shieh L, Hadhazy E, Cheng N, Khari P, Maggio P: Improved blood utilization using realtime clinical decision support. Transfusion 2014;54: 1358-1365.

35 Goodnough LT, Shah N: Is there a 'magic' hemoglobin number? Clinical decision support promoting restrictive blood transfusion practices. Am J Hematol 2015; 90:927-933.

36 Goodnough LT, Shah N: The next chapter in patient blood management: real-time clinical decision support. Am J Clin Pathol 2014;142:741-747.

37 Murphy MF: Application of bar code technology at the bedside: the Oxford experience. Transfusion 2007;47(2 suppl):120S-124S; discussion 130S-131S.

38 Pagliaro P, Turdo R, Capuzzo E: Patients' positive identification systems. Blood Transfus 2009;7:313318

39 Vuk T, Cipek V, Hecimovic A, Jukic I: Wrong blood in tube error: first study on donor blood samples. Transfusion 2014;54:1200-1202.

40 Sindhulina C, Joseph NJ: Addressing sample identification errors in a multispecialty tertiary care hospital in Bangalore. Vox Sang 2014;107:153-157.

41 Oldham J: Blood transfusion sampling and a greater role for error recovery. Br J Nurs 2014;23:S28, S30-24.

42 Chan JC, Chu RW, Young BW, Chan F, Chow CC, Pang WC, Chan C, Yeung SH, Chow PK, Lau J, Leung PM: Use of an electronic barcode system for patient identification during blood transfusion: 3-year experience in a regional hospital. Hong Kong Med J 2004;10: $166-171$.
43 Nuttall GA, Abenstein JP, Stubbs JR, Santrach P, Ereth MH, Johnson PM, Douglas E, Oliver WC Jr: Computerized bar code-based blood identification systems and near-miss transfusion episodes and transfusion errors. Mayo Clin Proc 2013;88:354-359.

44 Young D: Pittsburgh hospital combines RFID, bar codes to improve safety. Am J Health Syst Pharm 2006; 63:2431, 2435

45 Bertrand E, Schlatter J: Map of risks for the implementation of radio-frequency identification: application of ancillaries in the university hospital Jean Verdier. Pharmazie 2010;65:64-68.

46 Hohberger C, Davis R, Briggs L, Gutierrez A, Veeramani $\mathrm{D}$ : Applying radio-frequency identification (RFID) technology in transfusion medicine. Biologicals 2012; 40:209-213.

47 Sun PR, Wang BH, Wu F: A new method to guard inpatient medication safety by the implementation of RFID. J Med Syst 2008;32:327-332.

48 Marconi M, Langeberg AF, Sirchia G, Sandler SG: Improving transfusion safety by electronic identification of patients, blood samples, and blood units. Immunohematology2000;16:82-85.

49 Murphy MF, Kay JD: Barcode identification for transfusion safety. Curr Opin Hematol 2004;11:334-338.

50 Nichols JH, Bartholomew C, Brunton M, Cintron C, Elliott S, McGirr J, Morsi D, Scott S, Seipel J, Sinha D: Reducing medical errors through barcoding at the point of care. Clin Leadersh Manag Rev 2004;18:328334.

51 Sandler SG, Langeberg A, DeBandi L, Gibble J, Wilson C, Feldman CL: Radiofrequency identification technology can standardize and document blood collections and transfusions. Transfusion 2007;47:763-770.

52 Traynor K: Details matter in bedside bar-code scanning. Am J Health Syst Pharm 2004;61:1987-1988.

53 Knels R, Hans-Joachim M, Wittmann G, von Versen $\mathrm{R}$, Pruss A: Coding of tissue preparations with eurocode in Germany. Transfus Med Hemother 2012;39: 409-415.

54 Knels R, Ashford P, Bidet F, Bocker W, Briggs L, Bruce P, Csore M, Distler P, Gutierrez A, Henderson I, Hohberger C, Holcombe J, Holmberg J, Hulleman R, Marcel B, Messenger P, Mun I, Roberts S, Sandler G, Veeramani R, Wray B: Guidelines for the use of RFID technology in transfusion medicine. Vox Sang 2010; 98(suppl 2):1-24.

55 Dzik WH: New technology for transfusion safety. Br J Haematol 2007;136:181-190

56 Funk M, Günay S: Haemovigilance Report of the Paul-Ehrlich-Institut 2010. Assessment of the Reports of Serious Adverse Transfusion Reactions pursuant to Section 63 c AMG (Arzneimittelgesetz, German Medicinal Products Act). www.pei.de/SharedDocs/ Downloads/vigilanz/haemovigilanz/publikationen/ haemovigilance-report-2010.pdf?__blob= publicationFileぬ $v=5$ (last accessed February 15, 2017). 